\title{
Environmental Art Teaching Equipment and Program Research
}

\author{
Zou $\mathrm{Na}$ \\ Jilin Engineering Normal University, Chnia,130500
}

\begin{abstract}
Once the "Internet + " action plan is proposed, all walks of life actively take measures to integrate with the Internet. Higher education should also meet the requirements of the times to achieve new developments in education and teaching. Under the new situation, the education of environmental art design in colleges and universities should not only adopt the information-based teaching tools, but also take effective teaching new measures on the basis of the specific characteristics of the subjects, and turn passive learning into active learning to improve the teaching level and quality as well as cultivate innovative, skilled and applied talents that meet the needs of society.
\end{abstract}

\section{INTRODUCTION}

In the new situation, the development of the Internet has impacted the traditional art education model. For one thing, a single digital media classroom learning can no longer meet the needs of students' learning. The content of art teaching can't just stay in the textbooks. It must follow the changes of the times to design the teaching content. For another thing, the development of the Internet gives art. Education provides a broader platform, updated learning resources and more effective media and channels[1].

\subsection{THE INITIATIVE OF TEACHING METHODS}

In the traditional teaching mode, teachers often "self-directed and self-acting", and the teaching effect is not ideal. With the integration of learning software and application systems developed by various "Internet + " platforms into the student community, students can actively choose the appropriate learning style according to their own needs.

\subsection{THE IMPACT OF TEACHING RESOURCES INFORMATIONIZATION}

The era of environmental art design itself requires teachers and students to receive fresh design industry information. The traditional teaching resources are mainly the teachers' past experience and books and materials, which cannot be updated in time. The gap between schools and regions has led to certain differences in the allocation of teaching resources. The "Internet+" platform breaks through the limitations and lags of traditional teaching resources, enabling students and teachers to receive new industry dynamics and master new technologies more quickly, which realizes the sharing of teaching resources. The resources that were previously controlled by individuals are no longer "private ownership", but form an art resource pool. "Internet + " essentially promotes the construction of art resource libraries and curriculum information[2].

\subsection{THE DIVERSITY OF ART TEACHING MEDIA}

The Internet era has the advantages of new technologies and big data, and mobile devices have become a new learning medium, making learning more convenient. Combined with the diversity of courses in environmental art design, especially Auto CAD computer-aided design, Photoshop image processing, Wacom digital painting, 3Dmax three-dimensional production and other technologies have become the status quo of important professional expressions, only to accelerate the Internet information technology and college art education. In order to make the environmental art design course develop faster and more diverse, the emerging teaching modes such as "Mu Class", "Micro Lesson" and "Mobile Equipment + Internet" should be combined and made full use of. In addition, the combination of environmental art design teaching and more vivid three-dimensional virtual 3D technology can make art theory knowledge and practical operation more interesting and vivid.

\section{2 "INTERNET +" ENVIRONMENTAL ART DESIGN PROFESSIONAL TEACHING MODE ANALYSIS}

\subsection{TEACHING STAFF}

For the teaching staff engaged in education, the pace of keeping up with the times is not only the renewal of knowledge, but also the reform of teaching methods. The classroom of environmental art design in colleges and universities should not be limited to teachers' unilateral 
indoctrination and regulations. Instead, students should be provided with learning resources, professional guidance, learning in interactive communication, and growing in exploration. Therefore, for the teacher, the "Internet + " art teaching mode is a mode of changing the teaching concept and teaching behavior. It can fundamentally achieve the teaching link from the students' needs and carry out the real student-oriented teaching[3].

\subsection{RECIPIENTS}

For students who are educated, learning is not an individual's behavior. Mastering big data through "Internet +" can make learning no longer a lonely process, making it easier for students to recognize themselves and accurately recognize their own shortcomings. The direction of progress. In the "Internet + " environmental art design education, through online media.

\subsection{ART RESOURCES}

The grasp of trend information is an important part of art education. Environmental art design professional education can't always learn backward design thinking and technology. Only by mastering the latest industry development trends, technology and information can we achieve the goal of education. By taking the "Internet +" express train, art education has ushered in a rare opportunity in history, and the most cutting-edge design resources have entered the campus[4].

\section{CONSTRUCTION OF THE "INTERNET} +" ENVIRONMENTAL ART DESIGN TEACHING INNOVATION MODEL IN COLLEGES AND UNIVERSITIES

\section{1 "INTERNET +" LEARNING ENVIRONMENT CONSTRUCTION}

Different from traditional art education, "Internet+" creates a personalized teaching model and emphasizes the collaboration between students and teachers. The teaching implemented by "Internet + " can not only take care of the differences of individual students, but also facilitate students to recognize their own strengths and weaknesses and enhance their ability to acquire knowledge information for self-study. The advantage of developing "Internet + " teaching is that it can mix and match online and offline teaching, and cultivate students' habit of "learning" outside the classroom. This requires teachers to start from the characteristics of students when designing teaching content, to join the introduction of multimedia resources and information, design discussion and collaboration. Only under the guidance of these teaching links, the Internet can truly exert its superiority, so that the virtual learning environment and the real learning environment form a perfect connection.

\subsection{DESIGN OF TEACHING INNOVATION MODEL BASED ON "INTERNET +" ENVIRONMENT ART DESIGN}

\subsubsection{COMBINING "MU CLASS" TO FORM A DIVERSIFIED TEACHING MODE}

MOOC Open online course platform. The disadvantages of the traditional classroom are that the method is fixed and the form initiative is limited. The students can neither choose the teacher at will, nor the teacher's lecture mode. The initiative of the class is in the hands of the teacher. The network teaching is completely different, with obvious advantages. There are many different teaching resources in the same course and the same knowledge point. Students can choose their own lecture style. MOOC was formed by the combination of information technology and classroom teaching. It was proposed and developed in 2008. It has attracted the attention of educators around the world. More and more students use this platform to learn the top courses in the country and the world. In China, excellent platforms such as Xuetang Online, Mutu Net, and Chinese college students' MOOC have entered the public's field of vision. The development of education should be based on the Internet. MOOC can first gather the educational resources of top schools, regardless of the number of students, time and place, receive students from different fields and regions, and learn more actively, professionally, and interactively, in essence and classroom education. Ordinary network video learning is different. The teaching of environmental art design in colleges and universities should take the initiative to enter the MOOC. More institutions and design workers should join the team of MOOCs to provide learners with deeper and higher quality knowledge.The development trend of mooc is as follows. 


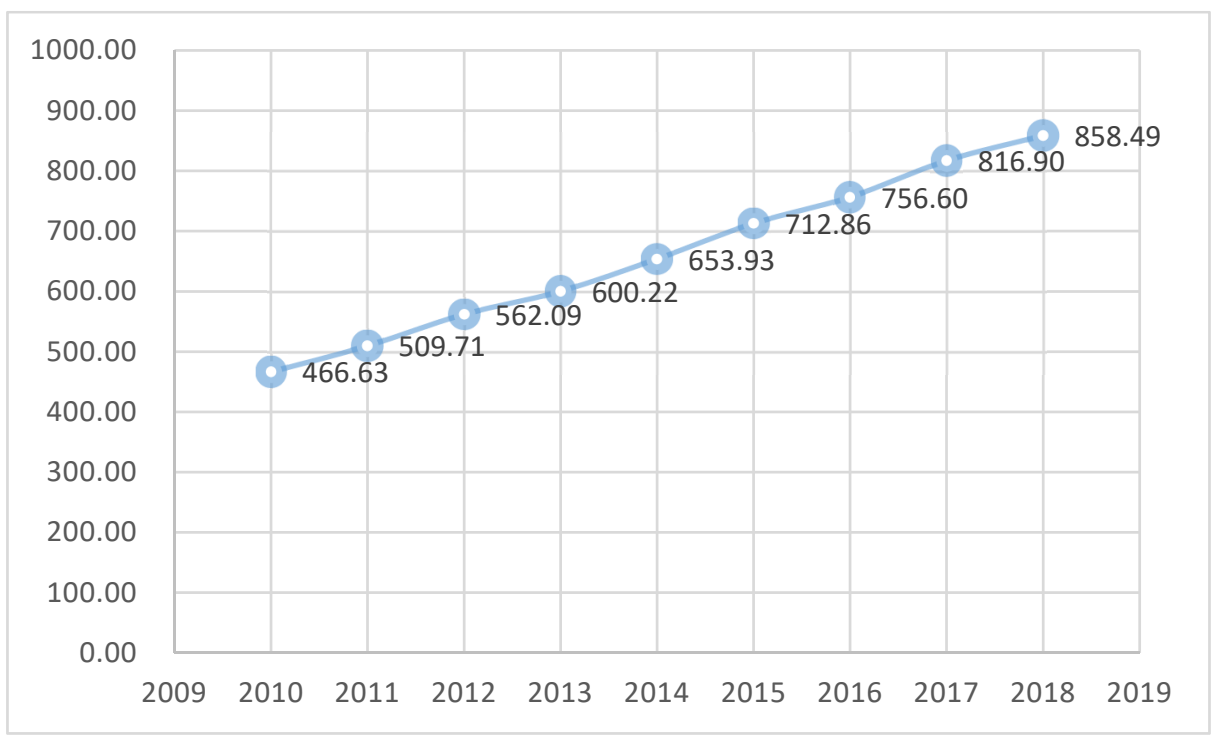

Figure 1: Development trend of mooc.

\subsubsection{ONLINE AND OFFLINE INTEGRATED ART TEACHING MODE}

Online learning includes the use of Internet courses, micro-courses, "mobile devices + Internet" to learn, but relatively independent online learning is more dependent on students' conscious, and can not fully achieve the purpose of teaching . Therefore, the development trend of "Internet + art teaching" in colleges and universities is not a single Internet teaching, but an online and offline integrated teaching innovation model.

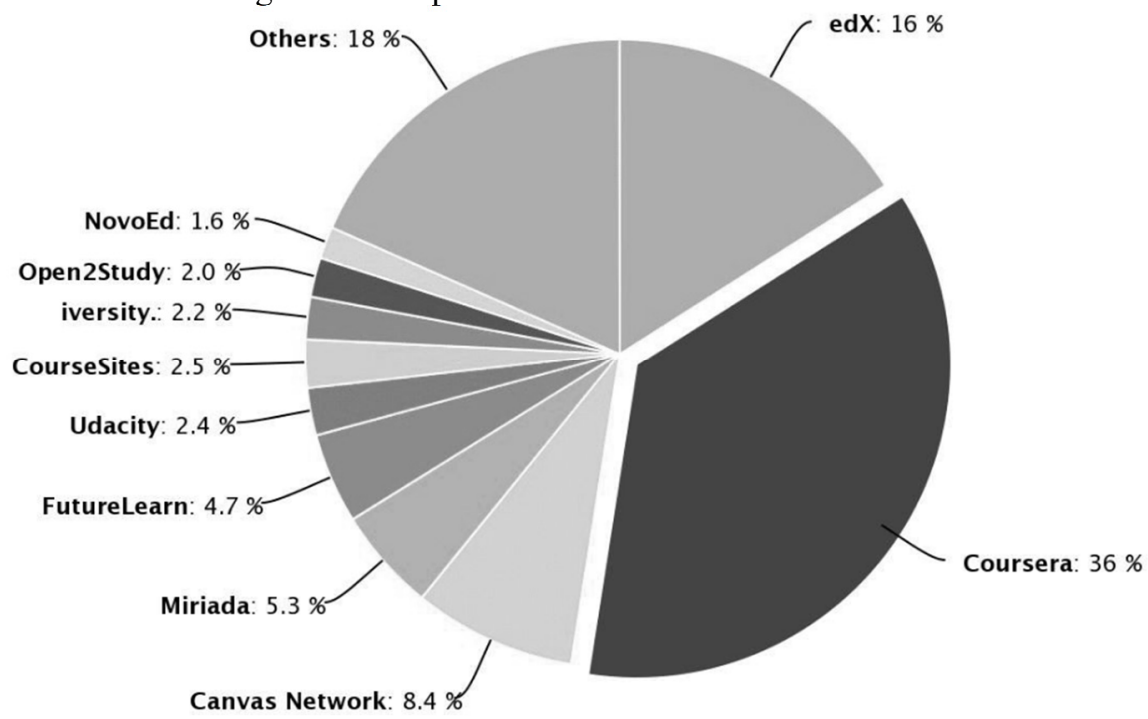

Figure 2: Market share of each educational website accounts.

(1) Internet self-study before class. Self-study does not stop at the study of book knowledge, but collects learning materials through various online channels for self-study. This requires effective guidance before the teacher's class, arranges the corresponding tasks according to the syllabus, and allows students to use the Internet platform to collect relevant knowledge points for learning before class, and archive them in the form of graphics and video for teacher inspection and class sharing. Resources. (2) Classroom combined with Internet interaction. With the support of the Internet, classroom learning can also be carried out in an innovative model. Change the traditional teaching mode, rely on specific projects, tasks, organize teachers and students to conduct practical teaching in the form of collaboration, and facilitate individualized management according to their respective abilities. (3) Internet resource sharing under the class. The end of the course does not mean the end of Internet learning, but a new beginning. The market share of each educational website accounts for the figure. Sharing your learning experiences and achievements through the platform will help you learn from each other and recognize your strengths and weaknesses. The design works of environmental art design students often reflect their design ideas and ideas intuitively. Sharing and sharing can prevent them from getting lost in their own thoughts. Through the cloud platform of the Internet, a resource sharing library is established, and students can consolidate after the course ends. 


\section{Conclusions}

The combination of art major and internet should not only be reflected in teaching, but also important in art innovation and entrepreneurship. We should integrate entrepreneurial ideas into teaching, guide environmental art design students to carry out innovative practice interactions in teaching forms and teaching content, use the spread of Internet information, and promote students to receive fresh information in the design industry, adapt to the pace of social development, and cultivate more Better original design talents help China gradually grow from a manufacturing power to a design power. "Internet + " has brought a new educational concept to college art education. The school education teaching method has more forms in time and space, and the teaching resource pool is unprecedentedly large. In the context of this informationization, how to combine the characteristics of environmental art design, use the advantages of the Internet to carry out educational innovation model design and curriculum reform, and improve the art teaching system is a test and challenge for professional educators.

\section{References}

1. Dan Zhang. Application Research on Computer Aided Design of Environmental Art Design Teaching[M].Springer Berlin Heidelberg:2012-06-15.

2. HASHIMOTO Tadakazu. Research the Educational Effects and the Tasks in introducing Environmental Art in the Teaching Materials of Art Classes at Elementary School : By Analyzing how Environmental Arts appear in Textbooks used in Art Classes at Elementary Schools[J]. Environmental Art and Design,2013,12(0).

3. Hen Friman. New Trends in the Higher Education: Renewable Energy at the Faculty of Electrical Engineering[J]. Energy Procedia,2017,115.

4. Hamzah Shanbari,Nathan Blinn,Raja R.A. Issa. Using augmented reality video in enhancing masonry and roof component comprehension for construction management students[J]. Engineering, Construction and Architectural Management,2016,23(6). 